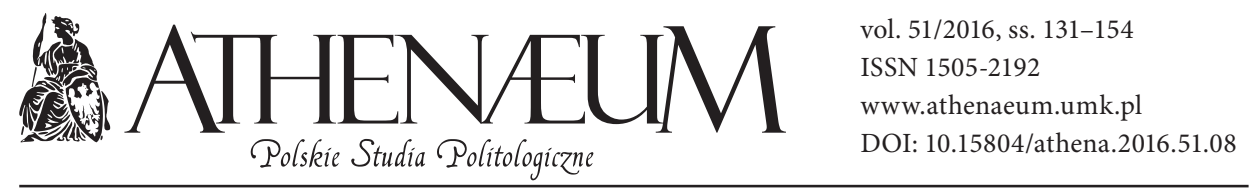

\title{
BUDŻET OBYWATELSKI INSTRUMENTEM ROZWOJU KAPITAŁU SPOŁECZNEGO
}

\author{
THE PARTICIPATORY BUDGETING AS AN INSTRUMENT \\ OF THE CIVIL SOCIETY DEVELOPMENT
}

Mateusz Radziszewski*

\begin{abstract}
ABSTRAKT
Artykuł jest analizą roli budżetu partycypacyjnego $\mathrm{w}$ procesie partycypacji społecznej. Przedstawione trzy modele jego funkcjonowania prezentują różny ich wpływ na jakość kapitału społecznego, czyli cechy społeczeństwa objawiające się wysokim poziomem zaufania, współpracy oraz więzi społecznych między obywatelami. W celu przeprowadzenia analizy zostanie zastosowana koncepcja kapitału społecznego i wspólnot obywatelskich Roberta Putnama.
\end{abstract}

Słowa kluczowe: Społeczeństwo obywatelskie, kapitał społeczny, partycypacja społeczna, budżet partycypacyjny, demokracja
The aim of the article is to analyse the functionality of the participatory budgeting (hereinafter: $\mathrm{PB}$ ) as an instrument of the social participation process. The article presents three models of the PB. They have a huge impact on the social capital, which is the networks of relationships among people based on trust, reciprocity and cooperation. The main goal is to make a scrutiny of the PB using Robert Putnam's research about the civil capital and civil communities.

Keywords: civil society, social capital, participation, participatory budgeting, democracy

* Uniwersytet Łódzki, Wydział Studiów Międzynarodowych i Politologicznych. 
Budżet obywatelski, nazywany również partycypacyjnym, od niedawna stał się filarem aktywizacji społecznej w wielu krajach świata, w tym także w Polsce. Szeroko zakrojone działania w celu stworzenia mechanizmów oraz zasad jego funkcjonowania, jako instrumentu partycypacji społecznej, a w konsekwencji rozliczne próby implementacji, skłaniają do stwierdzenia, iż stanowi on ważne narzędzie w procesie rozwoju społeczeństwa obywatelskiego (civil society). Ideą przyświecającą wszystkim z dotychczas przeprowadzonych przedsięwzięć aktywizujących społeczeństwo jest zwiększenie inkluzji obywateli w proces zarządzania miastem. Równie często podnoszonym argumentem jest to, iż stanowi on sposób na przekazanie części odpowiedzialności za proces tworzenia polityki mieszkańcom oraz zmniejszenie dysproporcji między różnymi grupami społecznymi. Władze miast oraz szereg organizacji pozarządowych inicjujących ten proces zmian, aby podkreślić znaczenie budżetu partycypacyjnego, wygłasza opinie, że to obywatele są najbardziej kompetentnym podmiotem do podejmowania decyzji na temat kierunków wydatkowania pieniędzy oraz potrzeb inwestycyjnych w przestrzeni lokalnej. Administracja publiczna ma jedynie pomagać w podjęciu tej decyzji oraz reagować na potrzeby lokalnej społeczności. Tego rodzaju rewolucyjne postrzeganie procesu politycznego skłania do refleksji nad wpływem budżetu partycypacyjnego na rozwój kapitału społecznego, świadomości, postaw obywatelskich lokalnych społeczności oraz proces komunikacji władz ze społeczeństwem.

Celem artykułu jest przedstawienie wpływu budżetu partycypacyjnego na rozwój kapitału społecznego poprzez wzmacnianie przez niego więzi społecznych. W szczególności należy wziąć tutaj pod uwagę procedurę partycypacji jako przejaw aktywności społecznej oraz jej efekty, czyli korzyści społeczne, które kształtują postawy obywateli i stanowią o jakości społeczeństwa obywatelskiego. Postawiono również następujące pytania badawcze: $\mathrm{z}$ jakich powodów tworzone są budżety partycypacyjne, jakie spełniają one funkcje w ramach budowy kapitału społecznego, czy są one instrumentem władzy, czy sposobem artykulacji interesów obywateli oraz jak wpływają na zwiększenie kapitału społecznego mieszkańców miast? Ponadto weryfikacji zostaną poddane następujące hipotezy:

H1: Budżet partycypacyjny wpływa na rozwój kapitału społecznego lokalnych wspólnot.

H2: Na obszarze wspólnoty rozwój kapitału społecznego w obrębie jednej grupy społecznej może spowodować jego spadek w innej.

H3: Budżet partycypacyjny ujawnia strukturę relacji i preferencji lokalnych społeczności. 
W niniejszych rozważaniach zostały wykorzystane dane znajdujące się w licznych publikacjach naukowych znawców tematyki, raportach ewaluacyjnych budżetów partycypacyjnych tworzonych przez instytucje państwowe oraz organizacje pozarządowe, jak również własne obserwacje kolejnych edycji tego przedsięwzięcia w Łodzi. Ponadto w celu zweryfikowania prawdziwości postawionych hipotez zostanie zastosowana koncepcja Roberta Putnama znajdująca się w jego publikacji Demokracja $w$ działaniu. Tradycje obywatelskie we współczesnych Włoszech z 1995 roku, mówiąca o kapitale społecznych budującym więzi społeczne i tworzącym wspólnoty obywatelskie.

\section{SPOŁECZEŃSTWO OBYWATELSKIE I KAPITAŁ SPOŁECZNY}

Społeczeństwo obywatelskie jako swego rodzaju zjawisko odciska znaczące piętno na państwie i społeczeństwie w wymiarze zarówno społecznym, ekonomicznym, jak i politycznym. Stanowi ono osnowę rozważań nad partycypacją społeczną oraz mechanizmem artykulacji potrzeb obywateli. Próba zdefiniowania ukazuje go jako wielopłaszczyznowy proces, istotny dla funkcjonowania struktury państwa oraz brzemienny w skutkach dla społeczeństwa. Odnosząc się do republikańskiego postrzegania tego pojęcia, w dziełach Arystotelesa oraz Cycerona zauważalne jest rozumienie obywatelskości jako pewnej powinności wobec ojczyzny oraz prawa do stanowienia o własnym państwie (Cyceron, 1999, Arystoteles, 2006). Powstałe w starożytności pojęcia koinonia politike (wspólnota polityczna) oraz jego rzymski odpowiednik societas civilis (społeczeństwo obywatelskie, ugrzecznione) kładą nacisk na postrzeganie człowieka jako istoty ludzkiej myślącej i prawdziwie wolnej jedynie w określonych ramach zbiorowości instytucjonalno-etycznej (Pietrzyk-Reeves, 2004, s. 18). Z kolei w liberalnej tradycji rozumienia pojęcia społeczeństwo obywatelskie tacy myśliciele, jak: J. Lock, A. Ferguson, J.S. Mill oraz A. de Tocqueville, kładą nacisk na nowe wymiary wolności: wolność ekonomiczna, samorządność, samoorganizacja w ramach struktur pozarządowych, a także wpływ na życie publiczne obywateli (Pietrzyk-Reeves, 2004, s. 70). Zgodnie z tym civil society jawi się jako struktura oderwana od aparatu państwa, będąca bytem odróżniającym się od władzy zwierzchniej, co w szczególności podkreślał J. Lock, twierdząc, że wolny człowiek stoi przed państwem i społeczeństwem, a zatem jego prawa są najważniejsze (Locke, 1992). Znaczenie tych dwóch tradycji postrzegania społeczeństwa obywatelskiego ukazał w zbiorze Cztery eseje o wolności (Berlin, 
1994). Autor mówi o istnieniu dwóch wolności: pozytywnej (wolności „do”) - czyli prawie do działania w myśl obiektywnej racjonalności na rzecz ogółu oraz wolności negatywnej (wolności „od”) - przestrzeni, w której człowiek jest wolny od ingerencji zewnętrznej (Berlin, 1994). Powyższe założenia kształtują percepcję społeczeństwa obywatelskiego oraz rolę budżetu partycypacyjnego $\mathrm{w}$ procesie jego budowania.

Szczególnie istotnymi w badaniach nad społeczeństwem obywatelskim w wymiarze implementacji budżetów partycypacyjnych są dokonania R. Putnama oraz J. Habermasa (Putnam, 1995, Habermas, 1999). Wzbogacili oni dorobek naukowy, nadając bardziej praktyczny wymiar prowadzonemu dyskursowi. Putnam wskazał na znaczenie tzw. miękkich czynników demokracji, czyli: obywatelskiego zaufania oraz sieci powiązań między obywatelami. Habermas natomiast podjął się próby analiz relacji władzy ze społeczeństwem, tworząc teorię komunikacji (Habermas, 2005). W duchu tych rozważań warto przywołać definicję społeczeństwa obywatelskiego stworzoną przez A. Chodurskiego, którego zdaniem powinno być ono postrzegane w aspekcie wolności i równości obywateli zamieszkujących wspólne terytorium, których działania skierowane są ku dobru wspólnemu (Chodubski, 2003, s. 165). Powyższe zaplecze teoretyczne stanowi szczególny powód do refleksji nad budżetem partycypacyjnym jako instrumentem komunikacji władz ze społeczeństwem oraz artykulacji przez nie swoich potrzeb i interesów.

Niezwykle ważnym aspektem badań nad społeczeństwem obywatelskim jest wykazanie empirycznych dowodów jego emanacji, jakości oraz skali. W tym celu należy wykorzystać pojęcie kapitału społecznego, które zdaniem Putnama jest zestawem cech społeczeństwa, takich jak: zaufanie, normy i powiązania (Putnam, 1995, s. 258).Z pewnością stanowi on ważną składową aktywności i partycypacji społecznej zaraz obok kapitału fizycznego i ludzkiego, które w bezpośredni sposób odnoszą się do sfery ekonomii. Putnam uważa, iż kapitał społeczny podnosi „produktywność” jednostek oraz całych grup społecznych (Putnam, 1995). Rozumieć ją należy jako intensyfikację powiązań między jednostkami w ramach sieci, w których obowiązują normy wzajemności oraz dominuje zaufanie do innych członków wspólnoty (Putnam, 1995). W całym tym procesie kluczową rolę odgrywają tzw. cnoty obywatelskie. Według Putnama są one tym silniejsze, im gęstsza jest sieć relacji społecznych, skutkiem czego społeczeństwo składające się z jednostek odznaczających się ową cnotą, jednakże równie mocno odizolowanych od siebie, nie wykazuje na tyle silnych więzi międzyludzkich, a tym samym nie posiada znaczącego kapitału społecznego (Putnam, 2008, s. 33). 
Kapitał społeczny ma oblicze zarówno indywidualne, jak i zbiorowe. Oznacza to, że poszczególni członkowie zbiorowości, wchodząc w interakcje ze swoimi sąsiadami, korzystają z niego, realizując własne interesy (Putnam, 1995). Z drugiej strony podejmując tego rodzaju aktywność, wpływają na rozwój całej grupy, budując wspólnotę. Należy podkreślić, że kapitał społeczny może dostarczać wielu korzyści, zarówno ekonomicznych, jak i społecznych. Dzięki niemu jednostki są w stanie realizować swoje potrzeby, nawiązując relację $\mathrm{z}$ innymi osobami, tym samym budując sieć kontaktów, które w wymiarze zarówno społecznym, jak i emocjonalnym mogą stać się powodem ogólnego dobrostanu (Putnam, 2008, s. 36). Płynie z tego wniosek, że w procesie tworzenia kapitału społecznego istotną rolę odgrywa zaufanie, które odnosi się zarówno do relacji między obywatelami, jak również między obywatelem a instytucjami państwa.

Jak dowodzi Putnam, społeczeństwo charakteryzuje się wzajemnością, w której relacje stają się bardziej efektywne, a mechanizm odwzajemniania „dobrych" uczynków może być oddalony w czasie jako dowód na istnienie silnych i długoterminowych relacji między obywatelami (Putnam, 1995). Mówiąc inaczej, wchodząc w interakcje z innymi członkami wspólnoty, nie oczekujemy bezpośredniego odwzajemnienia naszego działania, a jedynie mamy świadomość, że w przyszłości, gdy my będziemy potrzebowali pomocy, ktoś inny nam pomoże. Zatem relacje te nie stanowią tzw. ubijania interesu między obywatelami, a świadczą o budowaniu więzi społecznych. To poczucie uogólnionego zaufania i wzajemności do innych ludzi pozwala na zwiększenie partycypacji w procesie politycznym oraz umożliwia zachowanie partnerskich relacji na linii społeczeństwo - władza (Putnam, 2008). Należy jednak pamiętać, że kapitał społeczny rozwija się w różnych strukturach społecznych, a mogą być to: rodzina, klasa w szkole, członkowie klubu sportowego, pracownicy i pacjenci lokalnych przychodni lekarskich, pracownicy zakładów, osoby spotykające się w parku, grające w karty co niedziela, wreszcie organizacje obywatelskie, członkowie partii politycznych, ale również sąsiedzi w jednym domu przy tej samej ulicy (Putnam, 1995). Ważne jest jednak, aby odnaleźć sposób, w jaki może on zostać zmaksymalizowany i wykorzystany w celu tworzenia wspólnego dobra.

Zdaniem Putnama można wyróżnić dwie formy kapitału społecznego: łączący (bridging - tworzący sieć powiązań wśród członków różnych społeczności, np. wieś-miasto) oraz spajający (bonding - umacniający więzi i relacje wewnątrz grupy) (Putnam, 1995, s. 36). Pierwszy z nich pozwala na poszerzanie się grona osób wchodzących w relacje wzajemności, natomiast drugi odpowiada za wewnętrzną konsolidację w ramach lokalnej społeczności. Ważną cechą kapitału 
społecznego spajającego jest również budowanie wspólnotowej świadomości członków. Idą za tym również negatywne efekty, czyli możliwość powstania relacji antagonistycznych między skonsolidowaną wspólnotą a innymi grupami społecznymi.

Z powyższych ustaleń wynika, że kapitał społeczny stanowi o intensywności połączeń między obywatelami poprzez poziom społecznego zaufania, uogólnionej wzajemności między różnymi jednostkami oraz szeroko rozumianej współpracy. Tym samym stanowi on o istocie i jakości istniejącego na określonym obszarze społeczeństwa obywatelskiego. Warto zatem dokonać analizy procesu budowy kapitału społecznego w wymiarze implementacji budżetu partycypacyjnego w przestrzeni lokalnych samorządów.

\section{BUDŻET OBYWATELSKI INSTRUMENTEM PARTYCYPACJI SPOŁECZNEJ}

Budżet partycypacyjny stanowi istotne novum w procesie prowadzenia polityki na szczeblu lokalnym. Spośród różnych typologii budżetów partycypacyjnych warto odwołać się do tej, która wskazuje na istnienie trzech podstawowych modeli (Sintomer, Herzberg \& Röcke, 2007):

1. Klasyczny model Porto Alegre oparty na partycypacji grup interesu.

2. Fundusz komunalny jako element procesu komunikacji władz z mieszkańcami.

3. Bliska partycypacja (proximity participation), czyli dialog o finansach publicznych.

\section{Klasyczny model Porto Alegre oparty na partycypacji grup interesu}

Brazylia, chociaż nigdy nie słynęła $\mathrm{z}$ rozwiniętej formy demokracji, stała się prekursorem budżetu partycypacyjnego. Kilka lat przed jego zainicjowaniem rządy sprawowała tam prawicowa dyktatura, która nie dopuszczała do głosu obywateli. Każdy przejaw nieposłuszeństwa spotykał się z represjami ze strony aparatu państwa. Upadek lewicowych reżimów wschodniego świata oraz proces tranzycji systemowej w krajach dotychczas rządzonych przez prawicowe dyktatury w drugiej połowie lat 80 . stanowił szeroką falę przemian demokratycznych 
(Gianpaolo, 2005). Efektem tego procesu w Brazylii były pierwsze od 30 lat wolne wybory, które wygrali przedstawiciele lewicy (Souza, 2001, s. 161). Również na poziomie lokalnym władze zaczęły przejmować partie lewicowe, związane z szerokim prodemokratycznym ruchem społecznym (Santos, 2005). W Porto Alegre na burmistrza miasta został wybrany działacz związkowy związany z ugrupowaniem Partidos de Trabajadores, Olivio Dutra. Nie mógł on jednak cieszyć się pełnią władzy, gdyż jego działania spotykały się z oporem ze strony lokalnej legislatury, w której przedstawiciele jego ugrupowania nie uzyskali większości (Souza, 2001, s. 171). W celu wyjścia $\mathrm{z}$ impasu postanowiono stworzyć mechanizm, który dawałby władzy wykonawczej na tyle silną legitymizację ich działań, aby lokalna rada miejska nie mogła z przyczyn politycznych i wizerunkowych się jej sprzeciwić. Powstał zatem pomysł stworzenia budżetu partycypacyjnego, w który zaangażowani będą sami mieszkańcy Porto Alegre (Baiocchi, 1999).

Brazylijski model budżetu obywatelskiego stanowi jeden z przykładów rozwoju partycypacji społecznej. Proces jego tworzenia opierał się na konsultacjach przedstawicieli władz miasta $\mathrm{z}$ reprezentantami mieszkańców. Ci ostatni byli wybierani w trójstopniowej strukturze. Podstawowym zebraniem w Porto Alegre było zgromadzenie osiedlowe, które dokonywało wyboru delegatów do rad dzielnic, które to spośród swoich członków wybierały grupę reprezentującą interesy lokalnej wspólnoty (Kłębowski, 2013, s. 10). Na etapie pośrednim, przedstawiciele społeczeństwa sprawowali swoją funkcję tylko jedną kadencję, a w późniejszym okresie dwie. Byli oni pod stałą kontrolą mieszkańców i w każdej chwili mogli zostać odwołani. To właśnie na tym etapie tworzone były zhierarchizowane propozycje inwestycyjne. Najwyższy organ struktury stanowiła Rada Budżetu Partycypacyjnego, której członkowie również pozostawali pod stałą kontrolą mieszkańców, mogli zostać w każdej chwili zdymisjonowani, a sprawowali oni swoją funkcję przez okres dwóch rocznych kadencji (Santos, 1998). Należy dodać, że spotkania na każdym szczeblu były otwarte, a wszyscy traktowani byli równo (Kłębowski, 2013, s. 28). Ponadto w debatach uczestniczyli eksperci z ramienia władz miasta, którzy wspierali mieszkańców radą, zarówno w ramach gremialnych dyskusji, jak i wizytacji miejsc potencjalnych inwestycji. Ten model partycypacji cechuje brak bezpośredniego wpływu obywatela na propozycje, jakie zostaną zrealizowane w ramach budżetu. Partycypacja społeczna jest zatem ograniczona, a realny wpływ na nią mają osoby, które zasiadają w najwyższej rangą radzie, bezpośrednio prowadzącej rozmowy z włodarzami miasta. Kluczową rolę odgrywają tu liderzy opinii publicznej, znający problemy mieszkańców, będący powiernikami interesów różnych grup społecznych. Ich 
zadaniem w Radzie Budżetu Partycypacyjnego było przygotowanie dokumentu z propozycjami budżetowymi, a następnie zaprezentowanie go urzędnikom i członkom rady miejskiej. Wypracowany kompromisowy projekt budżetu miasta z punktu widzenia społeczeństwa nie podlegał zmianom. Jedynie Burmistrz mógł zawetować jego część lub odesłać projekt do komisji. Niemniej jednak nie widać, aby politycy nadużywali tych kompetencji, a jak dotychczas nie miało miejsca odesłanie całego projektu do ponownego rozpatrzenia.

Przykład Porto Alegre zainspirował kolejne miasta w Brazylii do wprowadzenia budżetu partycypacyjnego, czego przykładem jest Belo Horizonte. Przebieg kolejnych edycji w tych dwóch miastach pozwala sądzić, iż jest on dobrym kanałem artykulacji interesów i preferencji lokalnej społeczności. Dowodem na to są dane, które pokazują, że wdrożenie mechanizmów partycypacji społecznej wpłynęło na zwiększenie wydatków z budżetu miasta na opiekę zdrowotną oraz infrastrukturę sanitarną o 20-30\% w porównaniu z okresem, w którym nie był on stosowany (Gonçalves, 2014). Innym przykładem podkreślającym znaczenie głosu lokalnej społeczności jest to, iż w pierwszym roku jego funkcjonowania w Porto Alegre administracja przewidywała, że priorytetem dla najbiedniejszej grupy mieszkańców będzie transport publiczny, a w rzeczywistości okazało się, że był to dostęp do wody oraz rozbudowa miejskiego systemu kanalizacji (Souza, 2001). Należy więc stwierdzić, że budżet partycypacyjny tworzy możliwość artykulacji interesów mieszkańców oraz integruje obywateli wokół wspólnych problemów, pozwalając tym samym na zbudowanie wspólnoty obywatelskiej. Wśród kwestii uznanych przez mieszkańców Porto Alegre za priorytetowe znalazły się: ochrona zdrowia, szkolnictwo, bezpieczeństwo w mieście, regulacje dotyczące praw własności gruntów, infrastruktura drogowa (Gonçalves, 2014). W Belo Horizonte były to: budowa domów komunalnych, rozbudowa systemu kanalizacji, chodników, poprawa jakości życia w Fawelach, rozwój urbanistyczny miasta, ochrona zdrowia i edukacja (Souza, 2001, s. 167). Wprowadzenie budżetu partycypacyjnego w Brazylii zmieniło rozkład wydatków budżetowych we wszystkich miastach, gdzie został on wdrożony. Na przestrzeni lat nakłady na edukację wzrosły z 27\% w 1990 roku do 30\% w 2004 roku. Zauważalny jest również wzrost nakładów na opiekę społeczną i wodociągi o 10\% w ciągu 10 lat (Gonçalves, 2014).

Budżet partycypacyjny stał się nie tylko instrumentem zarządzania miastem, ale również kanałem komunikacji pomiędzy władzą a lokalną społecznością. Potwierdzają to wyniki badań opinii społecznej. 92,2\% ankietowanych w Porto Alegre oraz 88,9\% w Belo Horizonte stwierdziło, że chętnie bierze udział w spotkaniach. Pocieszające są również wyniki dotyczące zainteresowania 
wśród mieszkańców samą procedurą głosowania. Takowe wyraziło 75,5\% ankietowanych w Porto Alegre i 70,4\% w Belo Horizonte (Souza, 2001, s. 168-169). Budżet partycypacyjny zachęcił ludzi do samoorganizowania się i współdziałania, niemniej jednak zauważyć można stałą wyraźną niechęć do przejawów zinstytucjonalizowanej aktywności obywatelskiej w postaci partii politycznych i organizacji pozarządowych (z wyłączeniem społecznych ruchów sąsiedzkich). 40,7\% ankietowanych w Porto Alegre, a 37,3\% w Belo Horizonte uznało organizacje społeczne za przejaw obrony interesów lokalnej społeczności. Przeciwnego zdania było kolejno: $45,7 \%$ oraz 53,3\%. Reszta nie miała na ten temat własnego zdania (Souza, 2001). Po wprowadzeniu nowego instrumentu partycypacji społecznej w Porto Alegre z każdym rokiem wzrastała jednak liczba osób zaangażowanych w procedurę budżetową: 3,7 tys. osób w 1991, 10,7 tys. w 1993, 14,3 tys. w 1996 oraz 16 tys. w 1997 (Souza, 2001). Początkowo większość pochodziła jedynie z 6 na 16 dzielnic Porto Alegre, ale z czasem nastąpił znaczny rozwój aktywności społecznej. Zauważalna jest również wyraźna tendencja do zacieśniania współpracy między mieszkańcami. Badania pokazują, że w 1995 roku w spotkaniach tematycznych udział brała duża liczba osób zrzeszonych w organizacjach społecznych. Wyniki przeprowadzonych przez Bersa wywiadów potwierdzają ten fakt. 75,9\% ankietowanych przyznało się, że są członkami instytucji lub organizacji społecznych, a spośród nich 50,5\% organizacji sąsiedzkich. Zatem wśród szacowanych 16 tys. osób w 1997 roku, które brały udział w procedurze budżetowej, zdaniem Bersa, znajdowali się przedstawiciele 300 rozmaitych ruchów społecznych (Souza, 2001). Warto również przywołać badania Nylena przeprowadzone w Belo Horizonte, które pokazują, że przed wprowadzaniem budżetu partycypacyjnego w mieście do ruchów sąsiedzkich należało 52,2\% delegatów uczestniczących w procesie partycypacji, a po jego wprowadzeniu już 64,5\% (Souza, 2001). Jak widać, mieszkańcy dostrzegli potrzebę organizowania się i wspólnego artykułowania swoich potrzeb, gdyż tylko w takich sposób ich głos będzie słyszany, a oni będą mieli możliwość wpłynięcia na decyzje władz. Można zatem sądzić, iż jest to przejawem rozwoju kapitału społecznego, łączącego, zrzeszającego osoby $\mathrm{z}$ różnych środowisk i grup społecznych, które w ramach ruchu sąsiedzkiego postanowiły realizować wspólne interesy.

W analizie partycypacji społecznej lokalnych wspólnot szczególny nacisk należy położyć na korzyści, jakie czerpią z niej mieszkańcy. Kluczowym elementem, na jaki zwraca uwagę Santos, jest ten, iż każdy z uczestników budżetu partycypacyjnego miał prawo głosu w procesie formułowania priorytetów inwestycyjnych. Ponadto wybierani przez mieszkańców delegaci byli pod stałą 
kontrolą społeczeństwa (Santos, 1998). Fakt ten stoi w opozycji do postulatu Putnama o zaufaniu do siebie wszystkich członków lokalnej wspólnoty, jednakże jest dowodem na to, że partycypacja społeczna w modelu brazylijskim, nieustannie podlegała rozwojowi. Zmiany te były powszechnie aprobowane. Badania przeprowadzone w Belo Horizonte w 1994 pokazały, że wśród ankietowanych $67,3 \%$ uważa działania władz za akceptowalne, co pozwala sądzić, iż budżet partycypacyjny zwiększył również poziom zaufania społecznego do władz samorządowych (Santos, s. 170).

Dla potwierdzenia tego faktu należy przywołać słowa burmistrza Porto Alegre Oliwio Dutry: „Nie sprzedajemy iluzji bezpośredniej demokracji na greckim placu, która nie była demokracją wszystkich, ale demokracją najlepszych" (Sánchez i Aragonès, 2004, s. 2). Z badań przeprowadzonych przez Matthaeusa wynika, iż w 1995 roku 56,5\% biorących udział w badaniu w Porto Alegre stwierdziło, iż odczuwało satysfakcję z prac nad budżetem obywatelskim i efektów jego funkcjonowania (Souza, 2001, s. 170). W szóstym roku funkcjonowania budżetu partycypacyjnego tej samej odpowiedzi udzieliło 72,7\% ankietowanych. Badania przeprowadzone przez Somarriba i Dulcia w Belo Horizonte pokazują, że 85,1\% delegatów uczestniczących w pracach nad budżetem potwierdza jego efektywność. Ich zdaniem dzięki temu mechanizmowi społeczeństwo może wziąć udział w podejmowaniu decyzji nad publicznymi wydatkami (Souza, 2001). Jedynym problemem, jaki dostrzegają, jest mała ilość środków do rozdysponowania w ramach partycypacji społecznej. Inny, na który należy również wskazać, to mała liczba osób uczestnicząca w całej procedurze. W 1996 roku było to ok. 14,3 tys. osób, a według oficjalnych statystyk biorących udział w spotkaniach wszystkich szczebli mogło być nawet 100 tys., co stanowiło ok. 8\% całej populacji miasta (Souza, 2001). Nie zmienia to jednak faktu, że wydźwięk społeczny tego przedsięwzięcia był pozytywny i dalej pozostaje wzorem dla innych lokalnych samorządów.

Z przedstawionych danych wynika, że przyczyną powstania budżetu partycypacyjnego była rywalizacja polityczna władzy wykonawczej ze stanowiącą na szczeblu lokalnym. Pomimo tego stał się on ważnym instrumentem mobilizującym i integrującym lokalną społeczność. Jednocześnie wpłynął na wzmocnienie więzi społecznych, zachęcając do współpracy, wzmacniając m. in. zaufanie do współobywateli i władzy, tym samym rozwijając kapitał społeczny, co stanowi potwierdzenie dla pierwszej hipotezy. Widać zatem, że budżet partycypacyjny może być jednocześnie instrumentem władzy oraz kanałem komunikacji, dzięki któremu społeczeństwo artykułuje własne preferencje, co jest dowodem potwierdzającym prawdziwość trzeciej hipotezy. 


\section{Fundusz komunalny jako element procesu komunikacji} władz z mieszkańcami

Kolejny model budżetu partycypacyjnego znacznie różni się od jego pierwowzoru. Jego działanie polega na wyodrębnieniu tzw. funduszu komunalnego z całego budżetu miasta, który jest przeznaczony na propozycje mieszkańców. Projekty zgłoszone przez osoby zaangażowane w jego funkcjonowanie podlegają konsultacjom oraz są wybierane w ostatecznym głosowaniu lub poprzez stworzenie listy rankingowej priorytetów. Rolą władz jest natomiast sprawdzenie, czy dana propozycja może być, $\mathrm{w}$ myśl obowiązującego prawa, zrealizowana $\mathrm{z}$ funduszy lokalnego samorządu oraz konsekwentne wykonywanie wybranych inwestycji, $\mathrm{z}$ reguły w ciągu kolejnego, następującego po głosowaniu, roku budżetowego.

Przykładem państwa, w którym wprowadzono budżet partycypacyjny na poziomie lokalnym, jest Wielka Brytania. Wnioski płynące $\mathrm{z}$ analiz rządowych pokazują, że jest on mechanizmem zwiększającym zaangażowanie społeczne w proces decyzyjny, ale nie może być jedynym elementem funkcjonowania samorządu. Wraz z zastosowaniem go równolegle do innych instrumentów wykazuje znacznie większą efektywność. Jego wprowadzenie poprzedza niekiedy szereg inicjatyw rozbudzających partycypację społeczną, czego przykładami są miejscowości Manton i Thornhill (Department for Communities and Local Government, SQW, Cambridge Economic Associates, Geoff Fordham Associates, 2011, s. 101). Zaangażowanie lokalnej wspólnoty pozwala ujawnić jej kapitał społeczny, który szczególnie silnie zaznacza swoją obecność w małych środowiskach lokalnych, gdzie więzi społeczne są silniejsze, a przywiązanie do społeczności odgrywa kluczowe znaczenie, czego przykładem jest również miejscowość Thornhill (Department for Communities and Local Government, SQW, Cambridge Economic Associates, Geoff Fordham Associates, 2011).

Po raz kolejny należy podkreślić znaczenie efektów partycypacji. Kluczową rolę stanowi jakość proponowanych przedsięwzięć oraz sposób ich realizacji przez władze lokalne, co było niekiedy uznawane za duży problem, gdyż nie zawsze budżet partycypacyjny cieszył się poparciem lokalnych samorządów, a wypracowane pomysły nie były należycie realizowane (Department for Communities and Local Government, SQW, Cambridge Economic Associates, Geoff Fordham Associates, 2011). Jednym z efektów funkcjonowania budżetu partycypacyjnego jest zainicjowanie szerokiego dialogu społecznego na temat spraw wspólnoty. Przykładem takiej kooperacji jest Stockport, gdzie skupił się 
on wokół tematu bezpieczeństwa, a prace nad nim wspólnie prowadziła policja oraz lokalna społeczność (Department for Communities and Local Government, SQW, Cambridge Economic Associates, Geoff Fordham Associates, 2011, s. 86). Kultywowanie tego rodzaju zależności pozwala również efektywniej wykorzystywać środki publiczne. Wśród licznych angielskich budżetów partycypacyjnych odnajdziemy przykłady, kiedy to partycypacja społeczna pozwoliła na podniesienie jakości życia w zdegradowanych rejonach miasta oraz podjęcie działań w obszarach zapomnianych przez władze lub wcześniej nie uważanych za istotne. Ponadto budżet partycypacyjny pozwala na ujawnienie się lokalnych liderów opinii publicznej, którzy poprzez swoje zaangażowanie stają się powiernikami opinii grup społecznych, integrując wokół konkretnych pomysłów. Mamy tutaj do czynienia z procesem budowy kapitału społecznego łączącego osoby z różnych grup społecznych, których nie wiążą silne więzi społeczne, a partycypacja umożliwia im stworzenie wspólnej płaszczyzny współpracy. Z drugiej strony pozwala on na uaktywnienie się kapitału społecznego spajającego, w szczególności wśród członków organizacji pozarządowych, które jako pierwsze reagują na nowy model aktywności obywatelskiej. Badania jednak pokazują, że im dłuższa jest historia budżetu partycypacyjnego w danym mieście lub wsi, tym silniejsze stają się więzi społeczne, lokalnych środowisk (np. ruchy sąsiedzkie), które zaczynają dominować nad organizacjami pozarządowymi (Department for Communities and Local Government, SQW, Cambridge Economic Associates, Geoff Fordham Associates, 2011).

Budżet partycypacyjny integruje również osoby w różnym przedziale wieku. Dzięki niemu osoby młode, aktywne w przestrzeni samorządowej, mogą wykorzystywać wiedzę, jaką dostarczają im starsi przedstawiciele wspólnoty (The PB Unit, 2009, s. 42). Tym samym doświadczenie łączy się z młodością, tworząc nowy wymiar komunikacji wewnątrz społeczeństwa, jak również w relacji społeczeństwo - władza. Przykładem takiej silnej współpracy i konsolidacji lokalnej społeczności jest budżet partycypacyjny we wsi Eastfield, gdzie proces jego tworzenia od samego początku był efektem współpracy mieszkańców i władz samorządowych. Zostali w niego zaangażowani niemal wszyscy: uczniowie lokalnych szkół, tworzyli logo oraz materiały promocyjne, wolontariusze projektowali system komputerowy zliczający głosy, a pozostała grupa zapewniała catering dla wszystkich zaangażowanych w przedsięwzięcie. Akt głosowania miał miejsce w centralnym punkcie miasteczka, w tzw. centrum społecznym, czyli odpowiedniku naszego polskiego domu kultury jednego dnia, który nazwano The Decision Day. Ponad $90 \%$ osób uczestniczących w tym wydarzeniu stwierdziło po jego 
zakończeniu, że było ono otwarte dla wszystkich i uczciwe oraz że chętnie wezmą w nim udział po raz kolejny (The PB Unit, 2009, s. 35).

Z przedstawionych danych wynika, że implementacja budżetu partycypacyjnego miała miejsce przede wszystkim w małych lokalnych ośrodkach miejskich lub wiejskich. Liczba osób biorących udział w całym procesie nie przekraczała 500, a fundusze, jakimi dysponowali, były mniejsze bądź równe 100 tys. funtów. Potrzeby społeczne, które były uznawane za najważniejsze, to: aktywizacja ludzi młodych, przeciwdziałanie przestępczości, troska o środowisko naturalne, działania na rzecz społecznej spójności i aktywności (Department for Communities and Local Government, SQW, Cambridge Economic Associates, Geoff Fordham Associates, 2011, s. 10). W procedurze budżetowej szczególnie chętnie brali udział ludzie młodzi, chociaż w wielu przypadkach współdziałanie nie było zależne od żadnych podziałów społecznych. Badania opinii publicznej przeprowadzone w marcu 2010 roku, za pośrednictwem internetu, pokazują, że znaczna część osób uważa budżet partycypacyjny za ważny instrument aktywności obywatelskiej, dający ludziom możliwość decydowania o lokalnym środowisku (The PB Unit, 2009).

Z powyższych danych wynika, że powodem powstania budżetu partycypacyjnego mogą być nie tylko odgórne decyzje polityczne, ale również oddolne działanie lokalnej wspólnoty, jak miało to miejsce w Eastfield. Ponadto potwierdzają one, że budżet partycypacyjny mobilizuje i integruje lokalną społeczność, budując więzi współpracy i zaufania, rozwijając kapitał społeczny, potwierdzając tym samym prawdziwość pierwszej hipotezy. Nie odnalazła jednak swojego potwierdzenia druga $z$ hipotez. Ponadto przedstawione informacje dotyczące zmian w polityce lokalnej, np. rozwój zdegradowanych obszarów miasta oraz zmiany obszarów aktywności samorządu na te, które wcześniej nie znajdowały się w kręgu ich zainteresowań, potwierdzają trzecią z hipotez.

\section{BUDŻET OBYWATELSKI W POLSCE NA PRZYKŁADZIE ŁODZI}

Polska na mapie rozwoju partycypacji społecznej pojawiła się dość niedawno. Pomysł na wprowadzenie tego pomysłu pierwszy raz pojawił się w Płocku, gdzie w latach 2003-2005 stworzono „fundusz grantowy”, zwany również public/ private negotiation table, którego zadaniem było wsparcie lokalnych organizacji pozarządowych (Kłębowski, 2014). Pierwszy raz w Polsce w 2011 roku w Sopocie pojawiła się nazwa „budżet obywatelski” i to ten fakt uznaje się oficjalnie 
za początek jego istnienia. Zaraz za nadmorskim kurortem kolejne miasta postanowiły wprowadzić go u siebie. $Z$ analiz Fundacji im. Stefana Batorego wynika, że został on wprowadzony w ponad 70 gminach i miastach (Kraszewski i Mojkowski, 2014, s. 8).

Szczególnie interesującym miastem, w którym rozwinął się on w sposób znaczący, jest Łódź. Tutaj budżet obywatelski rozpoczął swoje funkcjonowanie w 2012 roku. W celu przeprowadzenia jego premierowej edycji powołano specjalny zespół złożony z miejskich radnych i urzędników. Do rozdysponowania przez mieszkańców przeznaczono 1\% budżetu miasta, czyli $20 \mathrm{mln}$ zł w kolejnym roku $30 \mathrm{mln}$ zł, a od $201440 \mathrm{mln}$ zł (Serzysko, 2014). Zadania, jakie mogły być zgłaszane przez mieszkańców, musiały być zgodne z kompetencjami miasta, a specjalny zespół weryfikujący spływające do niego wnioski skupiał się jedynie na kontroli formalnej (Serzysko, 2014). Po stronie pomysłodawców leżał obowiązek opisania projektu, jaki chcą, aby został zrealizowany, przedstawienia wstępnego kosztorysu inwestycji i zebrania 15 podpisów poparcia. Wszystkie one zostały uszeregowane w dwie kategorie: zadania ogólnomiejskie i lokalne (Serzysko, 2014). W 2016 roku budżet obywatelski w Łodzi będzie odbywał się $\mathrm{w}$ nowej formule. Tym razem fundusz komunalny nie będzie dzielony pomiędzy dzielnice i osiedla, gdyż stwierdzono, że są one bliższe koncepcji lokalnych wspólnot, a mieszkańcy utożsamiają się bardziej z nimi. Na efekty tej zmiany musimy jednak poczekać.

W głosowaniu w pierwszej edycji w 2013 roku udział wzięło 129 tys. osób, w drugiej 174834 osób, a w 2015 roku 136 tys. osób. Warto podkreślić, że partycypować w nim mogły jedynie osoby, które ukończyły 16 rok życia. Zgodnie z danymi ze spisu powszechnego z 2013 roku w Łodzi osób w wieku powyżej 16 lat jest ok. 622 tys. (Ludność - dane o Łodzi 2014, 2015). Frekwencja zatem oscylowała w granicach 21\% w 2013,28\% w 2014 i 22\% w 2015. W analogicznym okresie w sopockim budżecie obywatelskim wzięło udział 6,8\% w 2013, 15,14\% w 2014, 9,5\% w 2015, natomiast w Poznaniu ten odsetek wyniósł: 20,5\% w 2013, $12,6 \%$ w 2014, a 17\% w 2015. Z badań przeprowadzonych w 2013 roku wynika, że największą frekwencję zebrała edycja w Zielonej Górze 38\%, a najmniejszą w Rybniku 1\% (Osiecka i Cieślak - Wróblewska, 2014). Poniższy wykres prezentuje zestawienie liczby wniosków złożonych na przestrzeni trzech lat w łódzkim budżecie obywatelskim. Jak widać, nie zmienia się ona znacząco. Zestawienie to, jak również frekwencja w kolejnych edycjach, pozwala sądzić, że istnieje grupa osób aktywnych, które biorą udział w życiu miasta, odznaczają się wyższym poziomem kapitału społecznego od pozostałej części jego mieszkańców, a ich 
liczba nie ulega znaczącej zmianie. Dowodzić to może faktu, że w przypadku polskich budżetów obywatelskich występuje zjawisko enklaw obywatelskich, czyli miejsc na mapie miast, gdzie mieszkańcy chętniej partycypują w życiu politycznym miasta, $w$ wyniku czego odznaczają się wyższym poziomem kapitału społecznego.

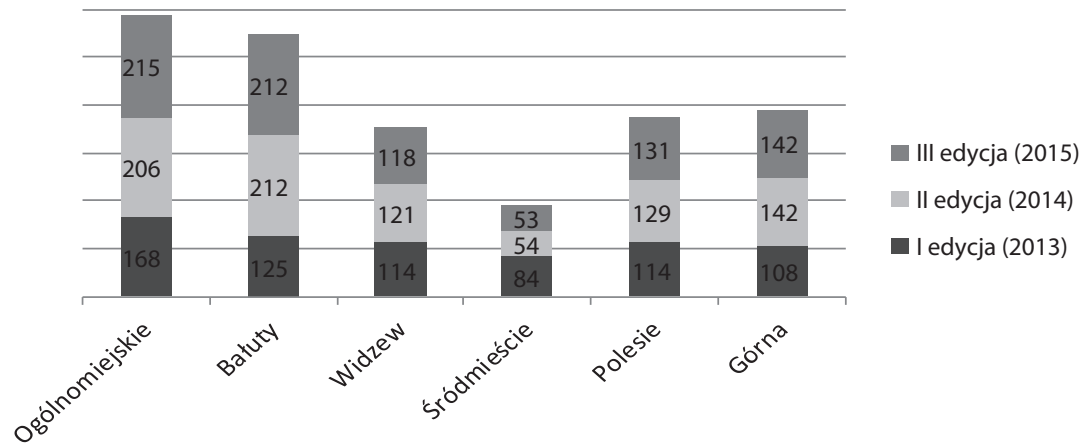

Wykres I. Liczba projektów przedłożonych pod głosowanie w kolejnych edycjach budżetu obywatelskiego.

Źródło: Zestawienie własne na podstawie: http://uml.lodz.pl/budzet_obywatelski/, 11.11.2015.

To, co w przypadku budżetu obywatelskiego w Brazylii i Anglii było uznawane za pozytywną cechę partycypacji, w Łodzi ogłoszono wypaczeniem idei obywatelskości. Spór dotyczył wybranych w głosowaniu projektów, które skupione były wokół następujących tematów: drogi, szkoły, ochrona zdrowia, sport, zieleń miejska. Podnoszono argument, że są to obowiązkowe zadania gminy i budżet obywatelski nie powinien służyć w celu uzupełniania niedociągnięć władzy. Te z nich określane jako infrastrukturalne skupione zostały wokół dużych osiedli, takich jak Widzew Wschód, gdzie bardzo intensywnie promowała swoje projekty Spółdzielnia Mieszkaniowa im. Chrobrego. Innymi instytucjami, którym udało się osiągnąć sukces w głosowaniu, były szkoły. Stanowiło to efekt współpracy kilku z nich, które na etapie promocji projektów postanowiły zawiązać współpracę i wspólnie walczyć o głosy. II edycja budżetu obywatelskiego w Łodzi również ukazała istnienie lokalnych społeczności, które odznaczają się silniejszym niż inne kapitałem społecznym, w szczególności łączącym, budując silne więzi społeczne wewnątrz osiedla. Przykładem tego jest znów dzielnica Widzew, gdzie 
gros projektów, które wygrały, dotyczyły remontów dróg, chodników, ścieżek rowerowych oraz szkół w kwartale ulic: Ćwiklińskiego, Czajkowskiego, Gorkiego i Gogola.

Poszukując odpowiedzi na pytania badawcze, należy stwierdzić, że powodem wprowadzenia budżetów partycypacyjnych w Polsce było zainteresowanie mieszkańców sprawami własnego miasta, tym samym podzielenie się z nimi odpowiedzialnością za jego zarządzanie. Potwierdza się również to, że spełnia on istotne funkcje, m.in.: integrując i mobilizując społeczność, jednocześnie wzmacniając więzi społeczne. Widać zatem rosnącą świadomość społeczną oraz potrzebę organizowania się, współdziałania oraz zaufania do współmieszkańców, co stanowi dowód na potwierdzenie pierwszej hipotezy. Kolejne edycje budżetu partycypacyjnego pokazują wyraźną potrzebę rozwoju kapitału społecznego, który stale pozostaje ograniczony jedynie do pewnej części mieszkańców miasta, co powoduje tworzenie się enklaw obywatelskich, co z kolei potwierdza prawdziwość drugiej z hipotez.

Nowa koncepcja budżetu opartego na osiedlach, z którymi utożsamiają się mieszkańcy, stanowi krok w stronę modernizacji struktury partycypacji społecznej. Wydaje się, że zmiana ta będzie miała pozytywne efekty, gdyż w dotychczasowej procedurze budżetowej środki przeznaczane na dzielnice zostawały w znaczącym stopniu zagospodarowywane przez osiedla, które posiadały więcej mieszkańców, wykazywały się silniejszymi więziami społecznymi lub stanowiły obszar działalności lokalnych społeczników. Nowa formuła budżetu partycypacyjnego pozwoli na wyartykułowanie potrzeb osiedli dotychczas znajdujących się w cieniu swoich silniejszych społecznie sąsiadów. Brak reakcji na tę dysproporcję spowodowałby rozwarstwienie społeczne oraz narastanie frustracji, które w konsekwencji doprowadziłoby do wypaczenia idei partycypacji społecznej. Powyższe problemy potwierdzają jednak, że budżet partycypacyjny stanowi ważny wskaźnik preferencji oraz ujawnia strukturę relacji w ramach lokalnej społeczności, co stanowi potwierdzenie trzeciej hipotezy.

\section{Bliska partycypacja - Proximity participation}

Przykładem państwa, w którym rozwinął się odmienny sposób postrzegania partycypacji społecznej, są Niemcy. Zwiększająca się tam co roku liczba budżetów partycypacyjnych implementowanych w przestrzeni wiejskiej oraz miejskiej nie wpływa na siłę głosu lokalnych wspólnot. Można je scharakteryzować 
poprzez 5 typów partycypacji (Buergerhaushalt.org, 2013). W pierwszej z nich mieszkańcy mają prawo jedynie do przedstawienia propozycji (proposal-based) do budżetu miasta. W badaniach Anny Reusch i Mandy Wagner z 2012 roku, spośród 96 budżetów partycypacyjnych, ten typ reprezentowało 41 . Obecnie aż $75 \%$ funkcjonujących budżetów partycypacyjnych umożliwia jedynie ten sposób partycypacji (Ruesch i Wagner, 2013). W kolejnym mieszkańcy mogą składać propozycje, które po wyborze przez władze lokalne muszą zostać przedstawione ponownie wspólnocie (proposal- and feedback-based) wraz z uzasadnieniem dokonanego wyboru (40 z 96 budżetów partycypacyjnych). Trzeci model daje możliwość mieszkańcom jedynie komentowania i oceniania propozycji przedstawionych przez władze lokalne (feedback-based). Tego typu budżetów w badaniu wystąpiło 8. Następnym przykładem jest tzw. decision - based, który stanowi niejako powielenie funduszu komunalnego, w którym władze lokalne jedynie potwierdzają wolę wyrażoną przez mieszkańców w kwestii wyborów zadań do zrealizowania ( 2 z 96). Ostatnia grupa to hybrydy, które znajdują się pomiędzy modelem proposial - based oraz proposial - and feedback - based (Buergerhaushalt.org, 2013).

Powszechnie przyjęta w Niemczech procedura budżetu partycypacyjnego składa się z trzech etapów. Pierwszy z nich polega na szerokich konsultacjach społecznych z mieszkańcami, którzy w ramach spotkań terenowych, poprzez specjalne informatory lub za pośrednictwem internetu mogą podzielić się wiedzą na temat: zasad tworzenia budżetu swojej miejscowości, reguł partycypacji w ramach tej procedury, kompetencji samorządu lokalnego oraz źródeł dochodów miasta, a także jego podstawowych wydatków.W drugiej fazie mieszkańcy przedstawiają własne propozycje do planu budżetowego oraz komentują już zgłoszone projekty. Lokalna społeczność prowadzi dialog na specjalnych portalach internetowych lub na spotkaniach terenowych i ocenia propozycje budżetowe. Efektem tych negocjacji jest lista propozycji przekazywana radzie miejskiej, która podejmuje decyzje o jej przyjęciu. Administracja samorządowa przygotowuje pisemne sprawozdanie ze zgłoszonych przez mieszkańców propozycji. W pierwszej kolejności oceniana jest wykonalność zgłoszonego zadania, jego koszty oraz czy mieści się ono w kompetencjach danego stopnia samorządu lokalnego. W ostatniej fazie władze przedstawiają efekty partycypacji w postaci wybranych propozycji, które zostaną zrealizowane wraz z argumentacją dokonania takiego wyboru. Jak można zauważyć, kluczowym powodem tak sformułowanej procedury jest uzyskanie dużej transparentności prowadzonych przez władze działań (Sintomer i in., 2010). 
Niemiecki model budżetu partycypacyjnego to specyficzny sposób inkluzji społecznej w proces tworzenia polityki na szczeblu lokalnym. Sprowadza się on przede wszystkim do sfery finansów samorządowych, szczególnie z powodu ograniczonych zasobów, ma na celu osiągnięcie większej transparentności decyzji władz oraz uzyskanie jak największych oszczędności. Kolejną cechą niemieckiego modelu partycypacji jest to, że istnieją trzy obszary, na których jest on wprowadzany: miasteczko, miasto lub dzielnica, a cała procedura została stworzona tak, aby na stałe wpisać się w proces polityczny na szczeblu lokalnym, nie ingerując znacząco w strukturę władzy samorządu lokalnego. Z raportu Buergerhaushalt.org - portalu informacyjnego zajmującego się problematyką partycypacji społecznej - wynika, że w ponad 150 miastach zaobserwowano proces wdrażania tego instrumentu w politykę lokalną (Buergerhaushalt.org, 2015). Obecnie w Niemczech funkcjonuje 71 zinstytucjonalizowanych budżetów partycypacyjnych, a znakomita ich większość znajduje się we Frankfurcie nad Menem i w Berlinie (Buergerhaushalt.org, 2016). Spośród wszystkich zaobserwowanych, $69 \%$ charakteryzuje się partycypacją mieszkańców w całej strukturze wydatków komunalnych. Procedura budżetowa tylko w niewielkiej puli została określona poprzez sztywne ramy tematyczne. W większości przypadków budżet partycypacyjny staje się instrumentem, który może mieć wpływ na całokształt tworzonego budżetu. $Z$ tego powodu największą popularnością cieszą się propozycje dążące do zminimalizowania wydatków publicznych. 79\% wszystkich budżetów partycypacyjnych pozwala na realizowanie propozycji obniżających koszty funkcjonowania samorządu oraz ustalania podstawowych wydatków (Buergerhaushalt.org, 2016).

Budżety partycypacyjne stają się instrumentem, w którego procesie funkcjonowania coraz częściej wykorzystywana jest technologia informacyjna. W Niemczech $40 \%$ z nich jest procedowanych za pośrednictwem stron internetowych, które zaczynają dominować nad tradycyjnymi zebraniami lokalnych społeczności; zaraz obok listów oraz rozmów telefonicznych są uważane za dodatkowe instrumenty partycypacji. Drugą co do wielkości grupę budżetów partycypacyjnych cechuje to, że odbywają się one jedynie w internecie (Buergerhaushalt.org, 2013).

Niemiecki przykład pokazuje, że budżet partycypacyjny nie zawsze wpływa na rozwój kapitału społecznego, a czasami jest jedynie efektem administracyjno-politycznej struktury procesu sprawowania władzy. Cechą ogólną niemieckiego modelu jest nieograniczony dostęp do informacji, ale również niewielkie zaangażowanie mieszkańców w proces podejmowania decyzji. Ponadto brak 
realnych efektów społecznych jego procedowania oraz jasnych zasad odpowiedzialności za całą procedurę. Z badań Buergerhaushalt.org wynika, że znakomita część z budżetów partycypacyjnych w Niemczech znajduje się w fazie projektowania lub konsultacji, a zatem funkcjonowanie tego instrumentu nie stanowi istotnego przejawu aktywności obywatelskiej Niemców.

Z powyższych ustaleń wynika, że niemiecki model budżetu partycypacyjnego nie wpływa na wzmocnienie więzi społecznych, jak również nie jest istotnym powodem podnoszenia poziomu zaufania w relacjach społeczeństwo - władza. Wskutek tego nie bierze on znaczącego udziału w procesie tworzenia kapitału społecznego (Sintomer i Gret, 2005). Nie należy jednak zarzucić władzom lokalnym złych intencji, chociaż arbitralny charakter podejmowanych decyzji przy roli mieszkańców jako konsultantów, z punktu widzenia innych modeli budżetu partycypacyjnego, wydaje się dalece odstawać od kanonu partycypacji społecznej, rozumianej w myśl idei budżetu partycypacyjnego. $Z$ tego powodu badacze partycypacji społecznej w Niemczech wnioskują o zwiększenie zaangażowania mieszkańców w proces tworzenia budżetów miejskich w wymiarze społecznym i politycznym (Ruesch i Wagner, 2013).

Odpowiadając na postawione we wstępie pytania, należy uznać, że powodem tworzenia budżetów partycypacyjnych w tym modelu jest chęć zwiększenia legitymizacji dla działań instytucji samorządu lokalnego. Stanowi on również przykład instrumentu władzy w rękach lokalnych decydentów, a nie sposobu na artykulację interesów mieszkańców. Wskutek tych ustaleń nie da się pozytywnie zweryfikować pierwszej hipotezy. W przypadku drugiej trudno jest odnaleźć rozłam w strukturze partycypacji społecznej, gdyż w niemieckim wydaniu jest ona dla wszystkich bardzo ograniczona i nie wpływa na rozwój postaw obywatelskich, ani na poziom kapitału społecznego. Trzecia hipoteza również nie może zostać potwierdzona, gdyż ten instrument nie odgrywa znaczącej roli w procesie partycypacji społecznej. Można przypuszczać, że tamtejszą strukturę relacji i preferencji lokalnych społeczności ujawniają inne przejawy partycypacji, jak np. organizacje pozarządowe lub ruchy miejskie, które samodzielnie wpływają na otoczenie, nie znajdując w budżetach partycypacyjnych możliwości istotnie silnej artykulacji własnych interesów. 


\section{PODSUMOWANIE}

Ustalenia, które zostały poczynione w tejże pracy, świadczą o tym, że budżet obywatelski jest ideą wpływającą na rozwój społeczeństwa obywatelskiego. Nie dziwi więc fakt, że w coraz większej liczbie państw trwają prace nad wdrożeniem go w proces polityczny na poziomie samorządów lokalnych. Przedstawione w artykule trzy modele budżetu partycypacyjnego prezentują różne wizje partycypacji społecznej. Każda z nich w odmienny sposób wpływa na rozwój kapitału społecznego, czyli cechy społeczeństwa objawiającej się wysokim poziomem zaufania, współpracy oraz więzi społecznych między obywatelami.

Klasyczny model brazylijski (partycypacja grup interesu) charakteryzuje się tym, że stwarza dogodne warunki do powstawania rozmaitych organizacji społecznych i ruchów sąsiedzkich. Jest to ważny wniosek, gdyż dzięki niemu mieszkańcy mają możliwość budowy kapitału społecznego łączącego przedstawicieli różnych grup społecznych wokół wspólnych problemów, a w dalszej fazie projektowania priorytetów są w stanie wzmocnić swój kapitał społeczny spajający w ramach powstałej uprzednio wspólnoty obywatelskiej. Z drugiej strony geneza powstania budżetu partycypacyjnego ujawnia, że instrument ten stanowi element rywalizacji politycznej pomiędzy lokalnymi elitami. Przeciwnicy idei wysuwali zarzut, że frekwencja podczas całej procedury budżetowej była mniejsza niż liczba głosów oddanych na radnych rady miejskiej Porto Alegre. Warto jednak zauważyć, że czynny udział w wyborach w Brazylii jest obowiązkowy, natomiast partycypacja w budżecie obywatelskim była dobrowolna.

Kolejny model budżetu partycypacyjnego (fundusz komunalny) pozwala zbudować wewnątrz lokalnej społeczności silne więzi społeczne. Jego przykłady w Wielkiej Brytanii i Polsce pokazują, że sprawdza się on najlepiej w ramach małych skupisk ludzi. Próby wprowadzenia go na większej przestrzeni powodują wytworzenie się obywatelskich enklaw, które odznaczają się większym kapitałem społecznym i dominują nad innymi częściami miasta, co stanowiło wniosek z procesu wdrażania budżetu partycypacyjnego w Łodzi. Nie można jednak stwierdzić, że cecha ta jest równie istotna we wszystkich badanych przypadkach. Powodami jej wystąpienia mogą być: dominujący na danym obszarze typ kultury politycznej lub struktura społeczna wspólnoty samorządowej.

Ostatni model budżetu partycypacyjnego (proximity participation) nie wykazuje tendencji do tworzenia kapitału społecznego wewnątrz lokalnej społeczności. Nie wpływa on także na podniesienie poziomu więzi społecznych między jej członkami. W tej koncepcji partycypacji obywateli pełni rolę arbitra. O sposobie 
procedowania budżetu oraz samym wyborze projektów do zrealizowania decydują władze lokalne. Brak w tej koncepcji realnych możliwości artykulacji własnych interesów lokalnej społeczności. Problem iluzorycznej partycypacji społeczeństwa podejmowany jest wielokrotnie przez niemieckich badaczy.

Poszukując odpowiedzi na postawione pytania badawcze, należy stwierdzić, że najczęstszym powodem powstawania budżetów partycypacyjnych jest odświeżenie procesu politycznego poprzez zwiększenie inkluzji politycznej lokalnej wspólnoty. Celem tych działań może być: uzyskanie przewagi siły na lokalnej scenie politycznej, zwiększenie legitymizacji dla działań władz bądź też zaangażowanie mieszkańców w celu podzielenia się odpowiedzialnością za funkcjonowanie samorządu. $Z$ tego powodu należy stwierdzić, że budżet partycypacyjny stanowi istotny instrument władzy w rękach decydentów politycznych, od których zależy, w jakim celu go wykorzystają. Niemniej jednak spełnia wiele istotnych funkcji w procesie rozwoju kapitału społecznego. Po pierwsze, mobilizuje do działania i integruje lokalną społeczność, tworząc więzi między jej członkami. Po drugie, wpływa na jakość kapitału społecznego łączącego, a po zinstytucjonalizowaniu się danego ruchu społecznego pozwala na spajanie relacji wśród jego członków. Następnie dąży do urzeczywistnienia postulatu uogólnionej wzajemności, co objawia się tym, iż lokalna wspólnota obywatelska poprzez współpracę dąży do wspólnego dobra. Nie można zatem jednoznacznie powiedzieć, czy budżet partycypacyjny stanowi tylko instrument władzy, czy też kanał artykulacji interesów wspólnot obywatelskich. Z przedstawionych danych wynika, że ma on potencjał do tworzenia się owych zbiorowości, które mogą odznaczać się wysokim poziomem kapitału społecznego. Sam budżet również wpływa na rozwój tego kapitału, natomiast czy będzie on polegał na dążeniu do zrealizowania wspólnego dobra, czy stanie się instrumentem w rękach zwalczających się grup społecznych, nie da się jednoznacznie określić. Należy pamiętać, że kapitał społeczny może być również wykorzystany do celów niekorzystnych z punktu widzenia całej wspólnoty.

W świetle powyższych danych należy stwierdzić, że hipoteza mówiąca o tym, że budżet partycypacyjny wpływa na rozwój kapitału społecznego lokalnych wspólnot, jest prawdziwa.

Brak jednak wystarczających danych, aby pozytywnie zweryfikować hipotezę mówiącą o tym, że na obszarze lokalnej wspólnoty (miasta, wsi) rozwój kapitału społecznego w obrębie jednej grupy społecznej może spowodować jego spadek w innej. Zjawisko to wymaga większej ilość danych empirycznych oraz ich pogłębionej analizy. 
Ostatnia hipoteza mówiąca o tym, że budżet partycypacyjny ujawnia strukturę relacji i preferencji lokalnych społeczności, również jest prawdziwa, gdyż zostało wykazane, że podczas procedowania go wytwarzają się tzw. wspólnoty obywatelskie, które z jednej strony rywalizują między sobą o zrealizowanie własnych interesów, ale przede wszystkim artykułują swoje postulaty, tym samym dając możliwość władzom lokalnym na pozyskanie informacji dotyczących struktury społecznej danego miasta, relacji między różnymi grupami społecznymi oraz preferencji potencjalnych wyborców.

Bibliografia:

Arystoteles (2006). Polityka. Warszawa: PWN.

Baiocchi, G. (1999). Participation, activism, and politics: The Porto Alegre experiment and deliberative democratic theory, Revised 11/1999. Wisconsin: University of Wisconsin - Madison.

Berlin, I. (1994). Cztery eseje o wolności. Warszawa: PWN.

Buergerhaushalt.org (2013). $6^{\text {th }}$ Status Report Participatory Budgeting in Germany (June 2013), Bonn: InWent gGmbH, Service Agency Communities in One World. Pobrane z: http://www.buergerhaushalt.org/sites/default/files/6._Status_report_buergerhaushalt.org_0.pdf.

Buergerhaushalt.org (2014). $7^{\text {th }}$ Status Report Participatory Budgeting in Germany (June 2014), Bonn: InWent gGmbH, Service Agency Communities in One World. Pobrane z: http://www.buergerhaushalt.org/sites/default/files/7th_Status_Report_2014.pdf.

Buergerhaushalt.org (2015). $8^{\text {th }}$ Status Report Participatory Budgeting in Germany (June 2015), Bonn: InWent gGmbH, Service Agency Communities in One World. Pobrane z: http://www.buergerhaushalt.org/sites/default/files/downloads/Status_report_2015_english.pdf.

Buergerhaushalt.org (2016). Map of Participatory Budgeting in Germany. Pobrane z: http://www.buergerhaushalt.org/en/map.

Chodubski, A. (2003). Jednostka, naród, państwo, Wprowadzenie do nauki o państwie i polityce. Lublin: Wydawnictwo Uniwersytetu Marii Curie-Skłodowskiej.

Cyceron (2009). O państwie, o prawach. Kęty: Wydawnictwo Antyk.

Department for Communities and Local Government, SQW, Cambridge Economic Associates, Geoff Fordham Associates (2011). Communities in the driving seat: a study of Participatory Budgeting in England. (Pobrane z: https://www.gov.uk/government/ uploads/system/uploads/attachment_data/file/6152/19932231.pdf.

Generalny Urząd Statystyczny (2014). Ludność - dane o todzi 2014. Pobrane z: http:// lodz.stat.gov.pl/dane-o-wojewodztwie/stolica-wojewodztwa-1323/ludnosc-dane-o-lodzi-2014/. 
Gianpaolo, B. (2005). Militants and Citizens. The Politics of Participatory Democracy in Porto Alegre. Stanford.

Gonçalves, S. (2014). The Effects of Participatory Budgeting on Municipal Expenditures and Infant Mortality in Brazil. World Development, Volume 53, s. 94-110.

Habermas, J. (1999). Teoria działania komunikacyjnego. Warszawa: PWN.

Habermas, J. (2005). Faktyczność i obowiązywanie. Teoria dyskursu wobec zagadnień prawa i demokratycznego państwa prawnego. Warszawa: Wydawnictwo Naukowe Scholar.

Kłębowski, W. (2013). Budżet partycypacyjny, krótka instrukcja obstugi. Warszawa: PWN.

Kraszewski, D., Mojkowski, K. (2014). Budżet obywatelski w Polsce. Warszawa: Fundacja im. Stefana Batorego.

Locke, J. (1992). Dwa traktaty o rządzie. Warszawa: PWN.

Pietrzyk-Reeves, D. (2004). Idea społeczeństwa obywatelskiego, współczesna debata i jej źródła. Wrocław: Wydawnictwo Uniwersytetu Wrocławskiego.

Polska Agencja Prasowa (2012). Raport socjologów na temat jakości życia mieszkańców Łodzi. Pobrane z: http://naukawpolsce.pap.pl/aktualnosci/news,392990,raportsocjologow-na-temat-jakosci-zycia-mieszkancow-lodzi.html. Ruesch, M.A., Wagner, M. (2013). Participatory Budgeting in Germany: Citizens as Consultants. Niemcy: Zebralog Gmbh \& Co KG. Pobrane z: http://www.internationalbudget.org/wp-content/uploads/Ruesch-Wagner-PB-in-Germany.pdf.

Putnam, R.D. (1995). Demokracja w działaniu. Tradycje obywatelskie we wspótczesnych Włoszech. Kraków: Społeczny Instytut Wydawniczy Znak.

Putnam, R.D. (2008). Samotna gra w kręgle, upadek i odrodzenie wspólnot lokalnych w Stanach Zjednoczonych. Warszawa: Wydawnictwo Akademickie i Profesjonalne.

Sánchez, S., Aragonès, E. (2004). A Model of Participatory Democracy: Understanding the Case of Porto Alegre. Edinburgh: School of Economics.

Santos, B. de S. (1998). Participatory budgeting in Porto Alegre: Toward a redistributive democracy. Politics \& Society, Volume 26 No. 4, s. 461-510.

Santos, B. de S. (2001). Participatory budgeting in Brazilian cities: limits and possibilities in building democratic institutions. Environment \& Urbanization, Volume 13 No. 1 , s. $159-184$.

Santos, B. de S. (2005). Democratizing Democracy. Beyond the Liberal Democratic Canon. London \& New York: Verso.

Serzysko, E. (red.) (2014). Standardy procesów budżetu partycypacyjnego w Polsce. Gdańsk: Fundacja Pracownia Badań i Innowacji Społecznych „Stocznia”. Pobrane z: http://partycypacjaobywatelska.pl/wp-content/uploads/2014/06/broszura-budzety-partycypacyjne1.pdf.

Sintomer, Y., Gret, M. (ed.) (2005). Participatory Budgets in a European Comparative Approach. Volume II. Berlin: Centre Marc Bloch Hans-Böckler-Stiftung.

Sintomer, Y., Herzberg \& C., Röcke, A. (2007). Démocratie participative et modernisation des services publiques: des affinités électives? Les budgets particiatifs en Europe. Paris: La Découverte. 
Sintomer, Y., Herzberg, C. \& Allegretti G., Röcke A. (2010). Learning from the South: Participatory Budgeting Worldwide - an Invitation to Global Cooperation. Bonn: InWent gGmbH, Service Agency Communities in One World.

The PB Unit (2009). Participatory Budgeting in the UK - A toolkit, Second Edition. Manchester: Church Action on Poverty. Pobrane z: http://www.pbpartners.org.uk/ wp-content/uploads/2013/11/Participatory-Budgeting-Toolkit.pdf. 